\title{
逆行性脳灌流における体外循環回路の工夫
}

\author{
遠藤久美子 浜松貴浩 長澤洋一
}

\begin{abstract}
要旨 当院では胸部大動脈手術の体外循環法として、25ํ以下超低体温循環停止下にて逆行性脳灌 流 (RCP) を選択している。循環再開時に大動脈末梢側の Air 抜きが必須となるが、その方法には、 大腿動脈を送血部位に使用している施設であれば、大腿動脈より逆行性にオーバーフローさせるな ど様々な方法があるが、問題点も多々指摘されている。その中で我々は RCP 灌流させたまま、送 血回路を利用して人工血管より大動脈末梢側のAir 抜きを行う方法を選択した。しかし、以前使用 していた回路では RCP と送血回路の同時送血が不可能であったため、回路に改良を加え、RCP 回路 を独立させ、同時送血を可能とした。
\end{abstract}

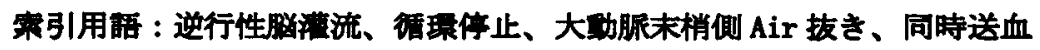

A new method of an extracorporeal circuration circuit for Retrograde cerebral perfusion. Kumiko Endoh, Takahiro Hamamatsu, Yoichi Nagasawa

Key words : Retrograde cerebral perfusion, circuratory arrest, a removal of air from distal aorta, simul taneous

[J Extra-Corporeal Technology 34(2): 128-131, 2007]

\section{I. 棤晋}

胸骨正中切開の胸部大動脈手術において、手術手 技や体外循環法は各施設の状況により様々であるが、 我々の施設では、上行および部分弓部大動脈人工血 管賉換術（以下、HAR）を行う際、直腸温 $25^{\circ} \mathrm{Cかつ}$ 豉膜温 $20^{\circ} \mathrm{C}$ を条件に循摆停止とし、逆行性脳灌流

（以下、RCP）を選択している。また、弓部大動脈人 工血管置換術（以下、TAR）を行う際には、同じく直 腸温 $25^{\circ} \mathrm{C}$ にて循環停止とし、RCP と選択的脳灌流(以 下、SCP) を併用して行っている。循環再開後の再循 環は、HAR の場合は大動脈遠位側吻合後、TAR の場合 には大動脈遠位側、左総頸動脈、腕頭動脈の伆合後 に行われる。再循環を開始する際、大動脈末梢側の

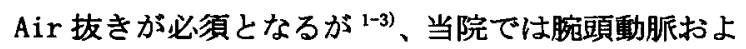
び左総頸動脈より逆流してくる RCP の血液で大動脈 末梢側を満たしていた。しかし、RCP の灌流量には 限界があり、Air 抜きに時間を要していた。2003 年 7 月に大動脈センターが開設され、症例数が急増し た（図 1)。更に時間短縮と術者の依頼も踏まえ、循 環再開時のAir 抜きを迅速かつ安全に行う目的で、 送血回路を利用し、大動脈末梢側 Air 抜きを行おう

(石心会川陭幸病院 大的腿センター $\mathrm{CE}$ 科 逗藤久美子 (Kumiko Endoh)

Department of $\mathrm{Cl}$ inical Engineering, Aortic Center, Kawasaki Saiwai Hospital

39-1, Miyako-cho Saiwai-ku, Kawasaki, Kanagawa 212-0016, Japan
としたが、以前使用していた回路では RCP と送血回 路の同時送血が不可能であったため、回路を改良す るに至った。

\section{II. 体外循而条件}

当院での体外循環条件を表 1 に示す。循環停止は 直腸温 $25^{\circ} \mathrm{C}$ 、かつ鼓膜温を $20^{\circ} \mathrm{C}$ 以下としている。 RCP の灌流量は $200 \mathrm{~mL} / \mathrm{min}$ を基本とし、回路内圧 $30 \mathrm{mmHg}$ を越える場合には灌流量を減少させている。また、 SCP は奇形や脳梗塞などの所見がない限り、左総頸 動脈と腕頭動脈の 2 本一送血し、左鎖骨下動脈は遮 断している。灌流量は 1 本当たり $4 \mathrm{ml} / \mathrm{kg} / \mathrm{min}$ とし、 メインポンプを使用して、術野で 2 又に分け濩流し ている。

\section{III. 体外循票手順}

当院での循環停止中の体外循鳋手順を図 2 に示寸。

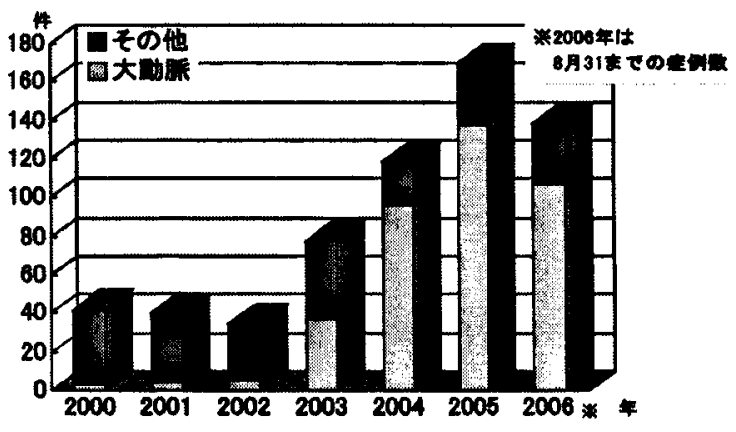

図 1 人工心肺症例数 
表 1 体外循環条件

\begin{tabular}{|c|c|c|c|}
\hline 脱血 & 上·下大䋖脈 & 2本脱血 & \\
\hline 送血 & $\begin{array}{l}\text { 上行大现愧 } \\
\text { 又は心尖部 }\end{array}$ & $2.0-2.5 \mathrm{ml} / \mathrm{min} / \mathrm{m}^{\circ}$ & 全てローラーP \\
\hline 休溘 & 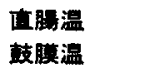 & $\begin{array}{l}25^{\circ} \mathrm{C} \text { 以下 } \\
20^{\circ} \mathrm{C} \text { 以下 }\end{array}$ & \\
\hline RCP & 上大静脈 & $200 \mathrm{ml} / \mathrm{min}$ & $\begin{array}{l}\text { 回路内压 } \\
\leqq 30 \mathrm{mmHg}\end{array}$ \\
\hline SCP & 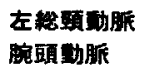 & $\begin{array}{l}4 \mathrm{ml} / \mathrm{kg} / \mathrm{min} \\
4 \mathrm{ml} / \mathrm{kg} / \mathrm{min}\end{array}$ & $\begin{array}{l}\text { 回路内压 } \\
\leqq 100 \mathrm{mmHg}\end{array}$ \\
\hline
\end{tabular}

\section{HAR}

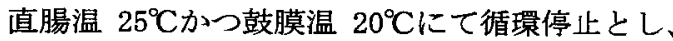
$\mathrm{RCP}$ を開始、大動脈遠位側吻合に移る。吻合後、大 動脈末梢側の Air 抜きを行い、人工血管近位側をク ランプ、RCP を終了し循環再開となり、復温を開始

\begin{tabular}{|c|c|c|c|c|c|c|c|}
\hline \multicolumn{4}{|c|}{ HAR } & \multicolumn{4}{|c|}{ TAR } \\
\hline & HA & $\mathrm{RCP}$ & $S C P$ & & Y⿰亻 & RCP & SCP \\
\hline \multirow[t]{3}{*}{ 需舟止 } & $\boldsymbol{c}$ & 9 & & $\operatorname{mon}$ & 6 & 9 & \\
\hline & & & & SCPカニュレージン & & & 9 \\
\hline & & & & 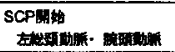 & & 6 & \\
\hline \multirow[t]{3}{*}{ 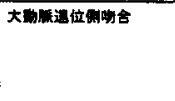 } & & & & 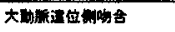 & & & \\
\hline & & & & 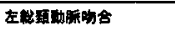 & & & 4 \\
\hline & & & & 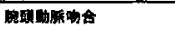 & & 9 & क \\
\hline 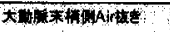 & 9 & & 1 & 大 & $\theta$ & & \\
\hline \multirow[t]{2}{*}{ 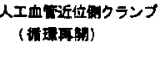 } & & t & & 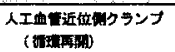 & & 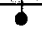 & \\
\hline & & & & 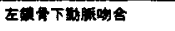 & & & \\
\hline 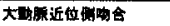 & & & & 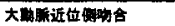 & & & \\
\hline
\end{tabular}

図 2 体外循環手順

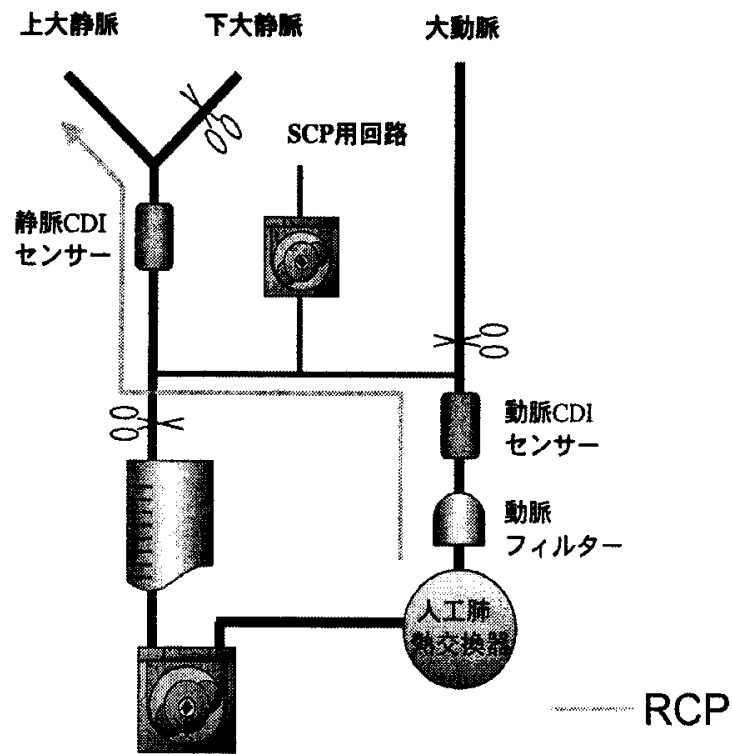

図 3 回路-改良前 (RCP)
する。続いて、大動脈近位側を吻合し、吻合後、大 動脈遮断解除となる。

\section{TAR}

$\mathrm{HAR}$ と同じく直腸温 $25^{\circ} \mathrm{C}$ か鼓膜温 $20^{\circ} \mathrm{C}$ に循環 停止とする。RCP を灌流させながら左総頸動脈およ び腕頭動脈へ SCP カニュレーションを行い、SCP 開 始後に RCP を終了する。このとき、RCP と SCP が一 時的に同時送血となる。次に大動脈遠位側を吻合し、 続いて左総頸動脈の吻合に移る。左総頸動脈吻合途 中で同血管の SCP が終了となる。次に腕頭動脈を吻 合するが、吻合途中 SCP を終了し RCP を開始する。 腕頭動脈吻合後、大動脈末梢側の Air 抜きを行い、 人工血管近位側をクランプ、RCP を終了し循環再開 となる。復温を開始し、次に左鎖骨下動脈を吻合、 続いて大動脈近位側を吻合し、吻合後、大動脈遮断 解除となる。

\section{IV. 体外偱環回路}

\section{1. 改良前}

以前の回路で RCP を行う場合、循環停止とともに 送血回路をクランプし、再循環回路を利用して脱血 回路から上大静脈一とメインポンプで RCP を灌流し ていた（図 3)。また、SCP を行う際には、再循環回 路より分枝させた回路で専用ローラーポンプにて灌 流していた（図 4)。

\section{2. 回路变更}

以前の回路では送血回路を使用する際、RCP は止 めざるをえなかった（図 5)。しかし循環再開時、大 動脈末梢側の Air 抜きを迅速に行うためには RCP と

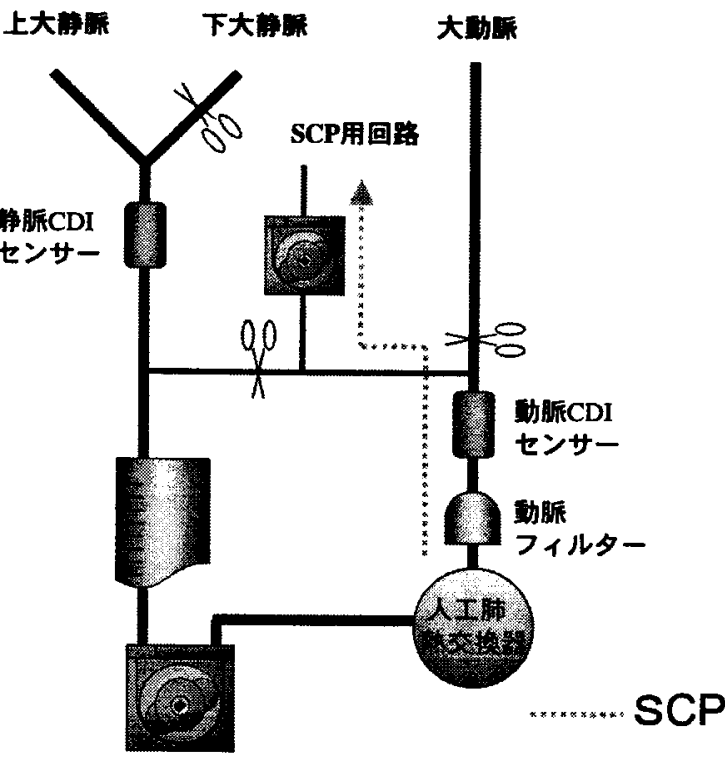

図 4 回路-改良前 (SCP) 
送血回路一の同時送血が好ましく、回路の改良を行 った。主な変更点は、RCP 回路を独立させたことで ある（図 6)。循環停止後、送血回路および脱血回路

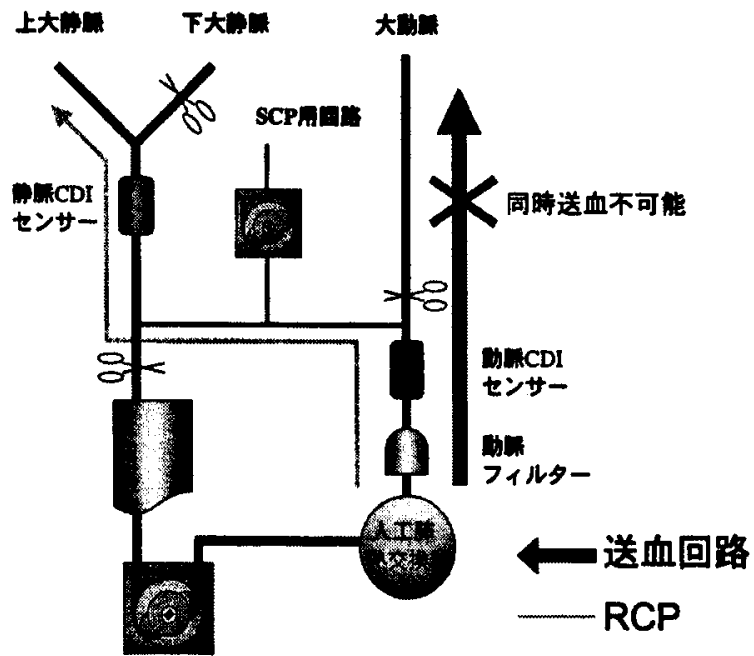

図 5 回路一問題点

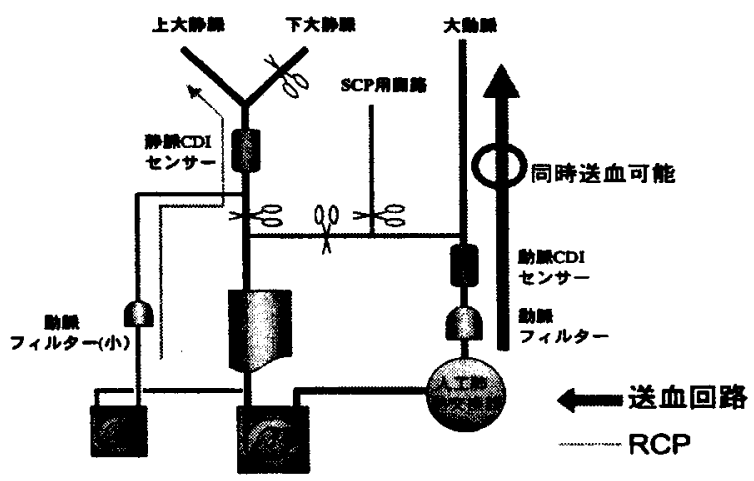

図 6 回路-改良後（同時送血）

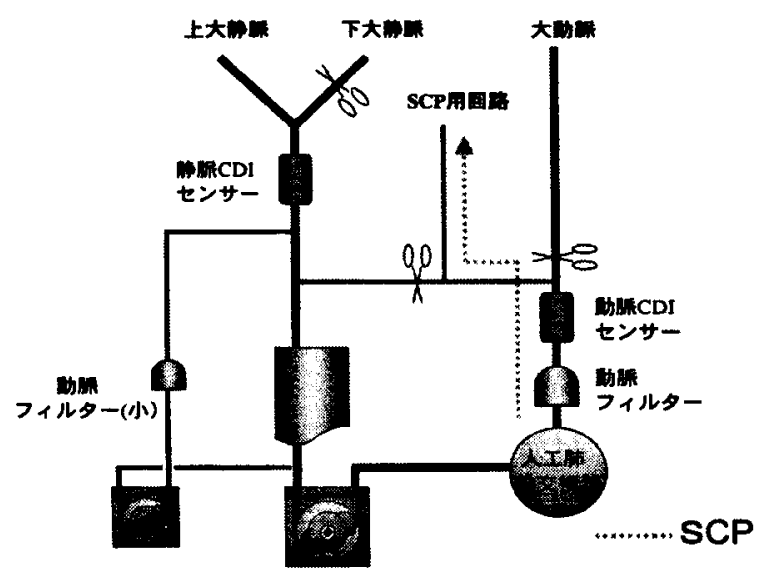

図 7 回路-改良後 (SCP)
の再循環回路と RCP 回路の間をクランプする。 RCP 回路は静脈リザーバーより直接専用ローラーポンプ を使用し、途中に動脈フィルターを介し脱血回路へ 合流させ、上大静脈一と灌流した。また、SCP にお いては回路を分枝させる場所は以前のまま、専用口 ーラーポンプを使用せずにメインポンプにて灌流を 行った（図 7)。

\section{V. 結 果}

RCP 回路を独立させたことにより、循環再開時に $\mathrm{RCP}$ と大動脈末梢側の同時送血が可能となった。そ のため、大動脈末梢側の Air 拔きを迅速かつ安全に 行えるようになった。しかし、RCP の回路構成にお いて、以前の回路ではメインの動脈フィルターを介 して送血していたが、今回の回路では静脈リザーバ 一から直接送血したため RCP 回路に小児用動脈フィ ルター（図 8）を追加した。そのため回路充填量が 以前に比べ $100 \mathrm{~mL}$ 増加してしまった。

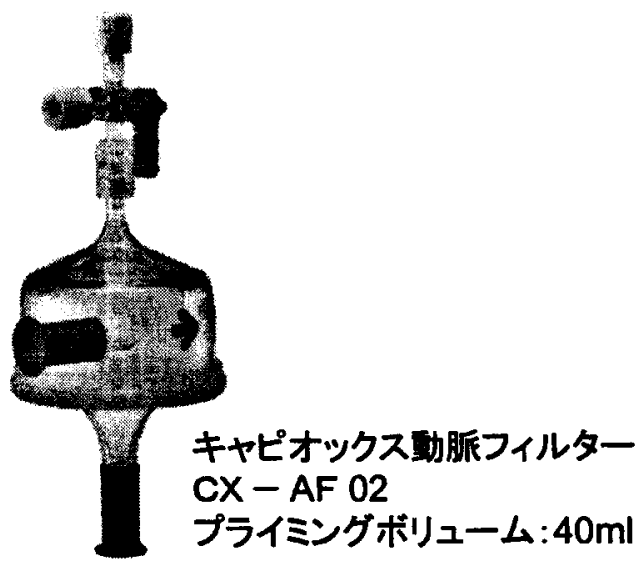

図 8 TERUMO 小览用動脈フィルター

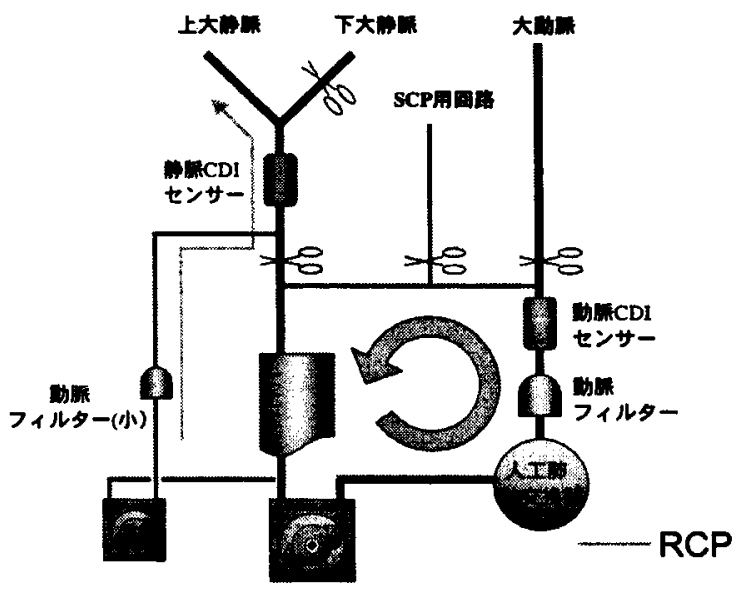

図 9 RCP 中の回路内再循環 


\section{VI. 考 察}

RCP 回路を静脈リザーバーから脱血したため、静 脈 $\mathrm{CDI}$ センサーの $\mathrm{PO}_{2}$ 濃度を確認しながら、酸素化 が必要な場合には回路内を再循環させた（図 9）。

しかし、その際に鉗子操作が必須となるので安全 性の向上には更なる改良が必要と考えられた。

\section{VII. 結 論}

RCP 回路を独立させたことにより循環再開時に $\mathrm{RCP}$ と大動脈末梢側への同時送血が可能となり、大 動脈末梢側の Air 抜きが迅速かつ安全に行えると考 えられた。
○参考文献

1）井野隆史：最新体外循環. 第 2 版, 東京, 金原出 版. 2003. p. 224-232.

2）高本眞一 監: 大動脈外科の要点と盲点. 初版, 東京, 文光堂. 2005. p. 110-126, 219-228.

3）阿部稔雄 : 最新人工心肺. 初版, 愛知, 名古屋大 学出版会. 2001. p. 174-180.

本論文は、第 32 回日本体外循環技術医学 会大会にて報告した。 